\title{
CHARACTERIZATION OF THE MOLLUSCICIDAL ACTIVITY OF Bauhinia variegata AND Mimusops elengi PLANT EXTRACTS AGAINST THE Fasciola VECTOR Lymnaea acuminata
}

Kanchan Lata SINGH, D.K. SINGH \& Vinay Kumar SINGH

\begin{abstract}
SUMMARY
The molluscicidal activity of Bauhinia variegata leaf and Mimusops elengi bark was studied against vector snail Lymnaea acuminata. The toxicity of both plants was time and concentration-dependent. Among organic extracts, ethanol extracts of both plants were more toxic. Toxicity of B. variegata leaf ethanolic extract $\left(96 \mathrm{~h} \mathrm{LC}_{50}-14.4 \mathrm{mg} / \mathrm{L}\right)$ was more pronounced than M. elengi bark ethanolic extract $\left(96 \mathrm{~h} \mathrm{LC}_{50}-15.0 \mathrm{mg} / \mathrm{L}\right)$. The $24 \mathrm{~h} \mathrm{LC}_{50}$ of column purified fraction of B. variegata and M. elengi bark were 20.3 $\mathrm{mg} / \mathrm{L}$ and $18.3 \mathrm{mg} / \mathrm{L}$, respectively. Saponin and quercetin were characterized and identified as active molluscicidal component. Comigration of saponin ( $\mathrm{R} f 0.48)$ and quercetin $(\mathrm{R} f 0.52)$ with column purified bark of $M$. elengi and leaf of B. variegata on thin layer chromatography demonstrate same $\mathrm{R} f$ value i.e. 0.48 and 0.52 , respectively. The present study clearly indicates the possibility of using M. elengi and/or B. variegata as potent molluscicide.
\end{abstract}

KEYWORDS: Molluscicidal activity; Plant species; Extracts; Lymnaeid vector; Fasciola; Snail; Lymnaea acuminata; Bauhinia variegata; Mimusops elengi.

\section{INTRODUCTION}

Fasciolosis is one of the most debilitating zoonotic diseases caused by the liver flukes Fasciola hepatica and Fasciola gigantica ${ }^{14-16,36}$. Incidence of fasciolosis is very common in the cattle of eastern region of the state of Uttar Pradesh in India ${ }^{24}$. The fresh water snail Lymnaea acuminata is the intermediate host of the $F$. gigantica ${ }^{29}$. This disease is at present emerging or re-emerging in many parts of the world such as Latin America, Europe, Africa and Asia ${ }^{16}$. Due to more attention on SARS, AIDS, malaria and research in immunological approaches to worm control, a little interest is focused on snail control to minimize the fasciolosis/ schistosomiasis ${ }^{11}$. One of the possible solutions to control fasciolosis is to disrupt the life cycle of Fasciola by killing the vector snail 1,9-11,27,35. The continuous and indiscriminate use of synthetic molluscicides for the control of vector snails has created a long detrimental effect on the aquatic environment ${ }^{22}$. Therefore, there is a need to develop a safe and eco-friendly counterpart of synthetic molluscicides. Molluscicides of plant origin are now gaining special importance because they are more effective, cheaper and safer to non-target organisms and culturally more acceptable ${ }^{8,27}$. The present study describes the molluscicidal activity of Bauhinia variegata (Order: Fabales; Family: Fabaceae) and Mimusops elengi (Order: Ericales; Family: Sapotaceae) against vector snail Lymnaea acuminata. Earlier it has been reported that organic (ether, chloroform and ethanol) extracts of B. variegata and M. elengi leaf and bark contain tannin, saponin, glycoside, terpenoids, flavonoids etc. ${ }^{5,6,8,19,25}$. Although large numbers of pharmacological effects of both the plants have been noted ${ }^{2,13}$, yet molluscicidal activity of these plants have not been reported till date.

\section{MATERIAL AND METHODS}

Plants Used: Fresh leaf of Bauhinia variegata and bark of Mimusops elengi were collected from Gorakhpur (India), washed thoroughly in running tap water and finally with sterile water, shade dried. The dried part of $B$. variegata leaf and bark of $M$. elengi were pulverized separately in the electric grinder and the crude powders were obtained, were then sieved with the help of fine mesh cloth. This fine powder was then used separately for toxicity experiments. The specimens were identified and authenticated by department of Botany DDU Gorakhpur University, Gorakhpur, India.

Solvent Extracts: Fifty grams of the leaf of B. variegata and bark of $M$. elengi were extracted separately with $100 \mathrm{~mL}$ of each solvent viz. ethanol (95\%), acetone (99\%), ether $(99.5 \%)$ and chloroform $(99 \%)$ at room temperature for $24 \mathrm{~h}$. Each preparation was filtered separately through sterilized whatman No.1 filter paper ${ }^{9}$ and the filtered extracts were subsequently evaporated under vacuum. The residues, thus obtained, were used for the determination of molluscicidal activity. The leaf of $B$. variegata yielded $220 \mathrm{mg}$ chloroform extract, $250 \mathrm{mg}$ acetone extract, $180 \mathrm{mg}$ ether extract, $300 \mathrm{mg}$ ethanol extract $M$. elengi bark powder yielded $180 \mathrm{mg}$ chloroform extract, $175 \mathrm{mg}$ ether extract, $190 \mathrm{mg}$ acetone extract, $210 \mathrm{mg}$ ethanol extract.

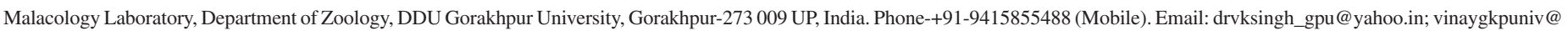
gmail.com

Correspondence to: Dr. Vinay Kumar Singh. E-mail: vinaygkpuniv@gmail.com. 


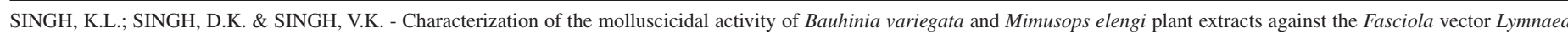
acuminata. Rev. Inst. Med. Trop. Sao Paulo, 54(3): 135-40, 2012.

Column purification: One hundred milliliters of $B$. variegata leaf ethanol extract and M. elengie bark ethanol extract were subjected to silica gel (60-120 mesh, Qualigens glass, Precious Electro Chemindus Private Limited, Mumbai, India) chromatography through $95 \times 45 \mathrm{~cm}$ column. Seventy five fractions of five milliliters were eluted with ethanol (95\%). Ethanol was evaporated under vacuum and the remaining solids obtained were used for the determination of molluscicidal activity of each fraction.

Thin Layer Chromatography: Thin layer chromatography (TLC) was performed by method of SINGH \& SINGH $^{31}$ as modified by JAISWAL \& SINGH ${ }^{9}$ to identify the active component present in $B$. variegata leaf extract and $M$. elengi bark extract. TLC was done on $20 \times 20$ $\mathrm{cm}$ precoated silica gel (Precious Electrochemical Industry. Pvt, Ltd, Mumbai, India). The solvent benzene/ ethyl acetate (9:1 v:v) was used as the mobile phase. Spots of column purified fractions of $B$. variegata leaf extract and $M$. elengi bark extract along with their respective active components quercetin and saponin were applied on TLC plates with the help of micropipette. Further, the TLC plates were developed by iodine vapor. Copies of the chromatogram were made by tracing the plates immediately and the retardation factor $(\mathrm{R} f)$ was calculated.

Pure Compound: Quercetin (3,3,4,5,7-penta hydroxyflavone) and saponin (Sapogenin 10-20\%) were procured from Sigma Chemical Co. USA.<smiles>O=c1c(O)c(-c2ccc(O)c(O)c2)oc2cc(O)cc(O)c12</smiles>

Chemical structure of Quercetin

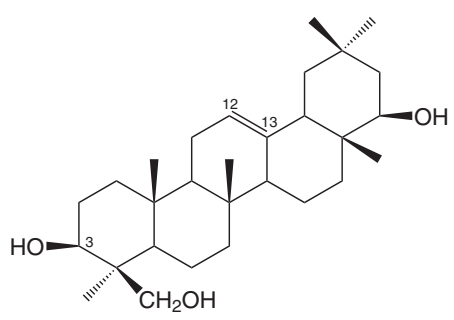

Chemical structure of Saponin
Collection of test animals: The adult fresh water snails, $L$. acuminata $(2.25 \pm 0.20 \mathrm{~cm}$ in length) were collected locally from different ponds, lakes and low lying submerged fields in Gorakhpur and were used as test animals. The collected snails were acclimatized for $72 \mathrm{~h}$ in the laboratory condition. Experimental animals kept in the glass aquaria containing dechlorinated tap water at $23 \pm 1{ }^{\circ} \mathrm{C}$. The $\mathrm{pH}$, dissolved oxygen, free carbon dioxide and bicarbonate alkalinity were 7.1-7.3, 6.5-7.3 mg/L, 5.2$6.3 \mathrm{mg} / \mathrm{L}$ and 102-105 mg/L, respectively. Dead animals were removed to avoid any spoilage of the aquaria water.

\section{Toxicity Experiment}

Concentration-response relationship: The toxicity experiments were performed by the method of SINGH \& AGARWAl ${ }^{28}$. Ten experimental animals were kept in a glass aquarium containing 31 of dechlorinated tap water. Snails were exposed continuously for $96 \mathrm{~h}$ to different concentrations of B. variegata leaf extract and M. elengi bark extract (Table-1). Six aquaria were set up for each concentration. The control animals were kept in equal volumes of water under similar conditions without treatment. Mortality of snails was recorded at intervals of $24 \mathrm{~h}$ up to $96 \mathrm{~h}$. The mortality of snails was established by the contraction of body within the shell; no response to needle probe was taken as evidence of death. The LC values lower and upper confidence limits (LCL and UCL), slope values, t- ratio, g-values and heterogeneity factor were calculated by using polo computer software of ROBERTSON et al. ${ }^{18}$ (2007). The regression coefficient between exposure time and different values of $\mathrm{LC}_{50}$ was determined by the method of SOKAL \& ROHLF ${ }^{32}$.

Table 1

Concentration of different plants products and their active components used for the toxicity determination against $L$. acuminata

\begin{tabular}{lc}
\hline Parts of plants and their extracts & Concentration $(\mathrm{mg} / \mathrm{L})$ \\
\hline B. variegata leaf powder & $100,150,200,250$ \\
Chloroform extract & $20,30,50,70$ \\
Ether extract & $20,30,50,70$ \\
Acetone extract & $20,30,50,70$ \\
Ethanol extract & $20,30,50,70$ \\
Column purified & $10,15,20,30$ \\
Quercetin & $7,9,12,15$ \\
M. elengi Bark powder & $30,50,70,120$ \\
Chloroform extract & $20,30,40,50$ \\
Ether extract & $20,30,40,50$ \\
Acetone extract & $20,30,50,70$ \\
Ethanol extract & $20,30,50,70$ \\
Column purified & $9,12,15,25$ \\
Saponin & $3,5,7,20$ \\
\hline
\end{tabular}

\section{RESULTS}

The toxicity of different organic solvent extracts of leaf powder of $B$. variegata and bark M. elengi was time and concentration dependent. The $24 \mathrm{~h} \mathrm{LC}_{50}$ of the leaf powder of B. variegata and bark powder of M. elengi was $244.70 \mathrm{mg} / \mathrm{L}$ and $91.19 \mathrm{mg} / \mathrm{L}$, respectively (Table-2 \& 3). There was a significant $(p<0.05)$ negative correlation between the $\mathrm{LC}_{50}$ and exposure time. B. variegata leaf ethanol extract $\left(24 \mathrm{~h} \mathrm{LC}_{50}-38.42 \mathrm{mg} / \mathrm{L}\right)$ and $M$. elengi bark ethanol extract $\left(24 \mathrm{~h} \mathrm{LC}_{50}-44.61 \mathrm{mg} / \mathrm{L}\right)$ were more toxic in comparison to other organic solvents (Table- $2 \& 3$ ). The column purified fraction of B. variegata and M. elengi were highly toxic. The maximum molluscicidal activity of column purified $B$. variegata leaf and $M$. elengi were noted in the 20-30 and 16-26 of the $5 \mathrm{~mL}$ Si-gel eluted fractions, respectively. The $96 \mathrm{~h} \mathrm{LC}_{50}$ of column purified fraction of $B$. variegata $(5.28 \mathrm{mg} / \mathrm{L})$ was higher than the M. elengi $(7.20 \mathrm{mg} / \mathrm{L})$ (Table- $2 \& 3)$. The $96 \mathrm{LC}_{50}$ of quercetin and saponin was $5.28 \mathrm{mg} / \mathrm{L}$ and $1.30 \mathrm{mg} / \mathrm{L}$, respectively. Thin layer chromatography analysis demonstrated that the $\mathrm{R} f$ values of quercetin (0.52) was equivalent to the $\mathrm{R} f$ value of column purified fraction of $B$. variegata $(0.52)$ and saponin $(0.48)$ was equivalent to the $\mathrm{R} f$ values of the column purified fractions of M. elengi $(0.48)$.

The slope values were steep and separate estimates of LC based on each of the six replicates were found to be within $95 \%$ confidence limit of $\mathrm{LC}_{50}$. The t-ratio was higher than 1.96 and heterogeneity factor was less than 1.0. The g-value was less than 0.5 at all the probability levels $(90,95,99)$. There was significant negative regression $(p<0.05)$ between exposure time and $\mathrm{LC}_{50}$ of the treatments (Table- $2 \& 3$ ). 
SINGH, K.L.; SINGH, D.K. \& SINGH, V.K. - Characterization of the molluscicidal activity of Bauhinia variegata and Mimusops elengi plant extracts against the Fasciola vector Lymnaea acuminata. Rev. Inst. Med. Trop. Sao Paulo, 54(3): 135-40, 2012.

Table 2

Toxicity of Bauhinia variegata leaf powder, organic solvent extracts, column purified fraction and quercetin (active component) against snail Lymnaea acuminata at different exposure periods

\begin{tabular}{|c|c|c|c|c|c|c|c|c|}
\hline \multirow{2}{*}{$\begin{array}{l}\text { Exposure } \\
\text { period }\end{array}$} & \multirow{2}{*}{ Tested materials } & \multirow{2}{*}{$\begin{array}{c}\mathrm{LC}_{50} \\
(\mathrm{mg} / \mathrm{L})\end{array}$} & \multicolumn{2}{|c|}{ Limits } & \multirow{2}{*}{$\begin{array}{l}\text { Slope } \\
\text { value }\end{array}$} & \multirow{2}{*}{ t-ratio } & \multirow{2}{*}{ g-value } & \multirow{2}{*}{ Heterogeneity } \\
\hline & & & LCL & UCL & & & & \\
\hline \multirow[t]{7}{*}{$24 \mathrm{~h}$} & B. variegata leaf powder & 244.70 & 216.22 & 302.00 & $3.78 \pm 0.68$ & 5.51 & 0.12 & 0.42 \\
\hline & Ethanol extract & 38.42 & 31.91 & 52.45 & $2.44 \pm 0.45$ & 5.42 & 0.13 & 0.17 \\
\hline & Ether extract & 57.19 & 40.90 & 134.30 & $1.77 \pm 0.44$ & 4.02 & 0.23 & 0.18 \\
\hline & Acetone extract & 38.64 & 32.78 & 50.35 & $2.84 \pm 0.49$ & 5.76 & 0.11 & 0.56 \\
\hline & Chloroform extract & 43.32 & 35.21 & 63.47 & $2.42 \pm 0.47$ & 5.16 & 0.14 & 0.34 \\
\hline & Column purified & 20.30 & 16.99 & 27.41 & $2.72 \pm 0.48$ & 4.16 & 0.12 & 0.28 \\
\hline & Quercetin & 12.13 & 10.42 & 24.73 & $2.19 \pm 0.62$ & 3.59 & 0.32 & 0.16 \\
\hline \multirow[t]{7}{*}{$48 \mathrm{~h}$} & B. variegata leaf powder & 203.45 & 179.12 & 245.20 & $3.03 \pm 0.60$ & 5.08 & 0.14 & 0.37 \\
\hline & Ethanol extract & 28.74 & 24.00 & 36.37 & $2.12 \pm 0.39$ & 5.35 & 0.13 & 0.15 \\
\hline & Ether extract & 34.78 & 27.91 & 51.28 & $1.84 \pm 0.39$ & 4.63 & 0.17 & 0.25 \\
\hline & Acetone extract & 30.09 & 25.41 & 37.95 & $2.31 \pm 0.41$ & 5.64 & 0.12 & 0.40 \\
\hline & Chloroform extract & 35.35 & 28.08 & 54.00 & $1.76 \pm 0.40$ & 4.46 & 0.19 & 0.29 \\
\hline & Column purified & 16.03 & 12.90 & 22.95 & $1.79 \pm 0.47$ & 3.16 & 0.14 & 0.32 \\
\hline & Quercetin & 9.86 & 8.45 & 13.75 & $2.16 \pm 0.60$ & 3.60 & 0.29 & 0.13 \\
\hline \multirow[t]{7}{*}{$72 \mathrm{~h}$} & B. variegata leaf powder & 155.94 & 137.78 & 174.18 & $3.52 \pm 0.58$ & 5.97 & 0.10 & 0.40 \\
\hline & Ethanol extract & 20.94 & 17.15 & 25.13 & $2.14 \pm 0.38$ & 5.58 & 0.12 & 0.18 \\
\hline & Ether extract & 20.74 & 17.13 & 24.66 & $2.25 \pm 0.38$ & 5.82 & 0.11 & 0.34 \\
\hline & Acetone extract & 21.47 & 17.75 & 25.70 & $2.20 \pm 0.39$ & 5.69 & 0.11 & 0.40 \\
\hline & Chloroform extract & 22.54 & 18.56 & 27.40 & $2.09 \pm 0.38$ & 5.43 & 0.13 & 0.31 \\
\hline & Column purified & 10.13 & 7.73 & 17.75 & $3.82 \pm 0.37$ & 3.60 & 0.14 & 0.28 \\
\hline & Quercetin & 6.82 & 4.79 & 9.93 & $4.75 \pm 0.60$ & 3.39 & 0.25 & 0.10 \\
\hline \multirow[t]{7}{*}{$96 \mathrm{~h}$} & B. variegata leaf powder & 126.70 & 110.93 & 139.72 & $4.35 \pm 0.63$ & 6.85 & 0.08 & 0.57 \\
\hline & Ethanol extract & 14.42 & 11.93 & 17.51 & $2.61 \pm 0.40$ & 6.49 & 0.09 & 0.66 \\
\hline & Ether extract & 15.03 & 12.00 & 17.67 & $2.57 \pm 0.40$ & 6.43 & 0.09 & 0.64 \\
\hline & Acetone extract & 15.50 & 12.52 & 18.00 & $2.70 \pm 0.40$ & 6.67 & 0.08 & 0.73 \\
\hline & Chloroform extract & 15.22 & 12.06 & 18.10 & $2.47 \pm 0.39$ & 6.22 & 0.10 & 0.76 \\
\hline & Column purified & 5.98 & 4.08 & 9.47 & $2.42 \pm 0.39$ & 5.16 & 0.13 & 0.33 \\
\hline & Quercetin & 5.39 & 4.81 & 8.41 & $3.96 \pm 0.64$ & 4.55 & 0.12 & 0.24 \\
\hline
\end{tabular}

Mortality was determined at every $24 \mathrm{~h}$ up to $96 \mathrm{~h}$. Each set of experiment was replicated six times. Abbreviation: B. variegata leaf powder $=$ Bauhinia variegata leaf powder; $\mathrm{LCL}=$ lower confidence limit; $\mathrm{UCL}=$ upper confidence limit. Significant negative regression $(p<0.05)$ was observed between exposure time and $\mathrm{LC}_{50}$ of treatments. Ts-testing significant of the regression coefficient - B. variegata leaf powder - 16.79+; Ethanol extract - 15.91+; Ether extract - 10.18++; Acetone extract - 17.30+; Chloroform extract. - 13.16+; column purified - 20.37+; quercetin - 6.55+. +: linear regression between $\mathrm{x}$ and $\mathrm{y}$; ++: non-linear regression between log $\mathrm{x}$ and log $\mathrm{y}$.

\section{DISCUSSION}

The present study clearly demonstrates that $B$. variegata leaf extract and $M$. elengi bark extract are the potent molluscicides. Mortality caused by all the plant preparations was time- and concentration dependent and there was a negative regression between exposure time and LC values. Toxicity of crude/ purified preparations of both plants against $L$. acuminata is in the range of potent molluscicide. Thus, high molluscicidal activity, the $\mathrm{LC}_{50}$ being less than $100 \mathrm{ppm}^{8,27}$. The $96 \mathrm{~h} \mathrm{LC}_{50}$ of crude preparations of both plants are approximately $100 \mathrm{ppm}$, whereas all organic extracts $\mathrm{LC}_{50}$ are less than $100 \mathrm{ppm}$. Among all the organic solvent extracts, the higher toxicity of ethanol extract of B. variegata leaf and M. elengi bark powder indicate that the active molluscicidal component present in the leaf and bark of both plants are more soluble in ethanol than other organic solvents. Molluscicidal activity of B. variegata leaf and M. elengi bark is due to the presence of quercetin and saponin as evident from the individual toxicity and identification by TLC. Earlier, it has been reported that saponins are potent molluscicides ${ }^{20,26,27,33}$. Pharmacological and biological effects of saponin as antibacterial ${ }^{7}$, antihelmintic ${ }^{13}$, antigastric ulcer $^{23}$ and hypotensive ${ }^{4}$ have been noted. Methanol extract of Mimusops elengi bark and seed shows significant antifungal activity ${ }^{21}$. Bark extract of $M$. elengi showed moderate inhibitory activity against HIV type-1 protease $^{12}$.

Bauhinia variegata, commonly known as 'cow paw', has great therapeutic properties, mainly due to the presence of flavonoids and other secondary metabolites include terpen, quinines and lactones ${ }^{3}$. Antiprotozoal, antihelmintic, antitumor, antiulcer and cytotoxic of $B$. variegata have been reported by CECHINEL FILHO ${ }^{2}$. Flavones and 
SINGH, K.L.; SINGH, D.K. \& SINGH, V.K. - Characterization of the molluscicidal activity of Bauhinia variegata and Mimusops elengi plant extracts against the Fasciola vector Lymnaea acuminata. Rev. Inst. Med. Trop. Sao Paulo, 54(3): 135-40, 2012.

Table 3

Toxicity of M. elengi bark powder, different organic solvent extracts, column purified fraction and saponin (active component) against snail Lymnaea acuminata at different exposure periods.

\begin{tabular}{|c|c|c|c|c|c|c|c|c|}
\hline \multirow{2}{*}{$\begin{array}{l}\text { Exposure } \\
\text { period }\end{array}$} & \multirow{2}{*}{ Tested materials } & \multirow{2}{*}{$\begin{array}{c}\mathrm{LC}_{50} \\
(\mathrm{mg} / \mathrm{L})\end{array}$} & \multicolumn{2}{|c|}{ Limits } & \multirow{2}{*}{$\begin{array}{l}\text { Slope } \\
\text { value }\end{array}$} & \multirow{2}{*}{ t-ratio } & \multirow{2}{*}{ g-value } & \multirow{2}{*}{ Heterogeneity } \\
\hline & & & LCL & UCL & & & & \\
\hline \multirow[t]{7}{*}{$24 \mathrm{~h}$} & M. elengi bark powder & 91.19 & 75.77 & 130.60 & $2.50 \pm 0.53$ & 4.72 & 0.17 & 0.20 \\
\hline & Ethanol extract & 44.61 & 35.37 & 70.40 & $2.17 \pm 0.44$ & 4.83 & 0.16 & 0.13 \\
\hline & Ether extract & 45.09 & 39.93 & 54.67 & $3.49 \pm 0.63$ & 5.48 & 0.12 & 0.13 \\
\hline & Acetone extract & 58.29 & 48.79 & 85.22 & $3.25 \pm 0.69$ & 4.65 & 0.17 & 0.30 \\
\hline & Chloroform extract & 52.81 & 46.40 & 66.46 & $4.12 \pm 0.75$ & 5.48 & 0.12 & 0.39 \\
\hline & Column purified & 18.34 & 10.50 & 57.75 & $2.19 \pm 0.34$ & 3.49 & 0.31 & 0.22 \\
\hline & Saponin & 15.57 & 13.68 & 19.88 & $4.02 \pm 0.78$ & 5.72 & 0.14 & 0.26 \\
\hline \multirow[t]{7}{*}{$48 \mathrm{~h}$} & M. elengi bark powder & 69.65 & 58.04 & 92.84 & $2.06 \pm 0.48$ & 4.29 & 0.20 & 0.25 \\
\hline & Ethanol extract & 31.38 & 25.46 & 43.72 & $1.85 \pm 0.39$ & 4.70 & 0.17 & 0.12 \\
\hline & Ether extract & 36.90 & 32.49 & 43.20 & $2.99 \pm 0.58$ & 5.13 & 0.14 & 0.15 \\
\hline & Acetone extract & 46.26 & 39.67 & 61.75 & $2.71 \pm 0.60$ & 4.52 & 0.18 & 0.22 \\
\hline & Chloroform extract & 46.49 & 40.26 & 60.09 & $2.96 \pm 0.61$ & 4.85 & 0.16 & 0.30 \\
\hline & Column purified & 15.71 & 8.07 & 17.27 & $1.76 \pm 0.28$ & 2.70 & 0.51 & 0.16 \\
\hline & Saponin & 13.90 & 11.78 & 17.82 & $3.20 \pm 0.28$ & 3.70 & 0.18 & 0.19 \\
\hline \multirow[t]{7}{*}{$72 \mathrm{~h}$} & M. elengi bark powder & 47.24 & 38.46 & 55.18 & $2.44 \pm 0.48$ & 5.09 & 0.14 & 0.42 \\
\hline & Ethanol extract & 21.71 & 17.74 & 26.33 & $2.06 \pm 0.38$ & 5.39 & 0.13 & 0.20 \\
\hline & Ether extract & 29.38 & 24.68 & 33.60 & $2.83 \pm 0.57$ & 4.94 & 0.15 & 0.18 \\
\hline & Acetone extract & 34.09 & 29.57 & 39.63 & $2.86 \pm 0.57$ & 4.89 & 0.16 & 0.23 \\
\hline & Chloroform extract & 34.25 & 30.38 & 38.87 & $3.31 \pm 0.58$ & 5.64 & 0.12 & 0.28 \\
\hline & Column purified & 10.60 & 9.18 & 12.41 & $4.76 \pm 0.28$ & 5.70 & 0.11 & 0.26 \\
\hline & Saponin & 4.25 & 2.99 & 7.06 & $1.89 \pm 0.26$ & 3.41 & 0.33 & 0.20 \\
\hline \multirow[t]{7}{*}{$96 \mathrm{~h}$} & M. elengi bark powder & 36.37 & 28.59 & 42.43 & $2.87 \pm 0.50$ & 5.66 & 0.12 & 0.72 \\
\hline & Ethanol extract & 15.07 & 11.83 & 17.89 & $2.40 \pm 0.39$ & 6.09 & 0.10 & 0.67 \\
\hline & Ether extract & 23.49 & 19.77 & 26.33 & $3.93 \pm 0.63$ & 6.23 & 0.09 & 0.49 \\
\hline & Acetone extract & 25.78 & 21.72 & 29.00 & $3.43 \pm 0.59$ & 5.75 & 0.11 & 0.56 \\
\hline & Chloroform extract & 26.02 & 22.06 & 29.21 & $3.48 \pm 0.60$ & 5.80 & 0.11 & 0.80 \\
\hline & Column purified & 7.20 & 5.74 & 8.15 & $3.84 \pm 0.28$ & 3.70 & 0.14 & 0.31 \\
\hline & Saponin & 1.30 & 0.27 & 2.16 & $0.69 \pm 0.25$ & 2.69 & 0.53 & 0.19 \\
\hline
\end{tabular}

Mortality was determined at every $24 \mathrm{~h}$ up to $96 \mathrm{~h}$. Each set of experiment was replicated six times. Abbreviation: M. elengi bark powder = Mimusops elengi bark powder; $\mathrm{LCL}=$ lower confidence limit; $\mathrm{UCL}=$ upper confidence limit. Significant negative regression $(p<0.05)$ was observed between exposure time and $\mathrm{LC}_{50}$ of treatments. Ts - testing significant of the regression coefficient - M. elengi bark powder - 9.09+; Ethanol extract - 6.68++; Ether extract - 19.54+; Acetone extract - 16.80+; Chloroform extract- 12.09+; column purified - 12.02+; Saponin - 4.96+. +: linear regression between x and y; ++: non-linear regression between log x and log y.

quercetin have been isolated from leaf of B. variegata ${ }^{17}$. Quercetin targets cysteine string proteins (CSP $\alpha)$ and impairs synaptic transmission ${ }^{37}$. The time dependent toxic effect of these plant products may be either due to the uptake of the active moiety which progressively increases the amount of active component in the snails body with increase in exposure period or it might be possible that the active compound could change into more toxic forms in the aquarium water or in the snails body.

A comparison of the molluscicidal activity of quercetin active component present in B. variegata and saponin present in M. elengi with synthetic molluscicides clearly demonstrates that these components are more potent against L. acuminata. The $96 \mathrm{~h} \mathrm{LC}_{50}$ of quercetin $(5.39 \mathrm{mg} / \mathrm{L})$ and saponin $(1.30 \mathrm{mg} / \mathrm{L})$ are lower than those of synthetic molluscicides carbaryl $(14.40 \mathrm{mg} / \mathrm{L})$, phorate $(15.0 \mathrm{mg} / \mathrm{L})$, formothion $(8.56 \mathrm{mg} / \mathrm{L})$ and niclosamide $(11.8 \mathrm{mg} / \mathrm{L})^{9,28} .96 \mathrm{~h} \mathrm{LC}_{50}$ of saponin $(1.30 \mathrm{mg} / \mathrm{L})$ and quercetin $(5.39 \mathrm{mg} / \mathrm{L})$ is even lower than active plant molluscicidal components of Allium sativum bulb $(271.06 \mathrm{mg} / \mathrm{L})^{31}$, Cinnamomum tamala $(830.90 \mathrm{mg} / \mathrm{L})^{34}$ Zingiber officinale rhizome $(273.80 \mathrm{mg} / \mathrm{L})$, Allium cepa bulb (253.27 mg/L); Trachyspermum ammi $(97.59 \mathrm{mg} / \mathrm{L})^{30}$.

It is evident from the steep slope values that a small increase in the concentration of different treatment causes mortality in snails. A t-ratio value greater than 1.96 indicates that the regression is significant. Values of the heterogeneity factor less than the 1.0 denote that in the replicates lines would fall within $95 \%$ confidence limit and thus the model fits the data adequately. The index of significance of potency estimating values indicates that the value of the mean is within the limits at all probability levels $(90,95,99)$ as it is less than 0.5 . 
SINGH, K.L.; SINGH, D.K. \& SINGH, V.K. - Characterization of the molluscicidal activity of Bauhinia variegata and Mimusops elengi plant extracts against the Fasciola vector Lymnaea acuminata. Rev. Inst. Med. Trop. Sao Paulo, 54(3): 135-40, 2012.

In conclusion, it can be stated that B. variegata and M. elengi extracts may be used as potent plant molluscicide as their active components are more toxic than their synthetic counterparts. Both plants are found abundantly in this area, so that it is easily available, ecologically safe and culturally more acceptable among native live-stock keepers. Further studies on these plants are needed to verify, whether the extracts of both plants are toxic to other invertebrate (mollusks and aquatic insects) or vertebrate (small fishes) sharing the same habitat with vector Lymnaea. The outcome will certainly give an idea that both plants can be used in aquatic environment with negative ecological consequences. More studies on the mode of action of active molluscicidal components in snail body are also required to explore its full potential as molluscicide.

\section{RESUMO}

\section{Caracterização da atividade moluscicida dos extratos das plantas Bauhinia variegata e Mimusops elengi contra o vetor da Fasciola, Lymnaea acuminata}

A atividade moluscicida das folhas da Bauhinia variegata e da casca do Mimusops elengi foi testada contra o vetor caracol, Limnaea acuminata. A toxicidade de ambas as plantas é dependente do tempo e da concentração. Entre os extratos orgânicos, os extratos de etanol de ambas as plantas foi mais tóxico. A toxicidade do extrato etanólico da folha da $B$. variegata $\left(96 \mathrm{~h} \mathrm{LC}_{50}-14,4 \mathrm{mg} / \mathrm{L}\right)$ foi mais pronunciada do que o extrato etanólico da casca do M. elengi $\left(96 \mathrm{~h}-\mathrm{LC}_{50}-15,0 \mathrm{mg} / \mathrm{L}\right)$. As frações purificadas em coluna durante $24 \mathrm{~h} \mathrm{LC}_{50}$ do B. variegata e da casca do M. elengi foram $20,3 \mathrm{mg} / \mathrm{L}$ e $18,3 \mathrm{mg} / \mathrm{L}$, respectivamente. A saponina e a quercentina foram caracterizadas e identificadas como os componentes ativos moluscicidas. A co-migração da saponina (Rf $0,48)$ e da quercentina ( $\mathrm{Rf} 0,52$ ) com a casca purificada por coluna do $M$. elengi e as folhas da $B$. variegata na cromatografia demonstraram o mesmo valor $\mathrm{Rf}$ isto é, 0,48 e 0,52 respectivamente. O presente estudo indica claramente a possibilidade de usar M. elengi e/ou B. variegata como moluscicidas potentes.

\section{ACKNOWLEDGMENTS}

Authors are thankful to University Grants Commission (UGC), New Delhi, India, for financial assistance (F. No. 39/590-2010 (SR).

\section{REFERENCES}

1.Agarwal RA, Singh DK. Harmful gastropods and their control. Acta Hydrochim Hydrobiol. 1988;16:113-38

2. Cechinel Filho V. Chemical composition and biological potential of plants from the genus Bauhinia. Phytother Res. 2009;23:1347-54.

3. Da Silva KL, Cechinel Filho V. Plantas do gênero Bauhinia: composição química e potencial farmacológico. Quím Nova. 2002;25:449-54

4. Dar A, Behbahanian S, Malik A, Jahan N. Hypotensive effect of the methanolic extract of Mimusops elengi in normotensive rats. Phytomedicine. 1999;6:373-8.

5. Dhale BA. Phytochemical screening and antimicrobial activity of Bauhinia variegata Linn. J Ecobiotechnol. 2011;3(9):4-7.

6. Gami B, Parabia MH. Pharmacognostic evaluation of bark and seeds of Mimusops elengi L. Int J Pharm Pharm Sci. 2010;2(Suppl 4):110-3.
7. Hazra KM, Roy RN, Sen SK, Laskar S. Isolation of antibacterial pentahydroxy flavones from the seeds of Mimusops elengi Linn. African J Biotechnol. 2007;6:1446-9.

8. Hostettmann K, Lea PJ. Biologically active natural product. Oxford: Oxford Science Publisher; 1987.

9. Jaiswal P, Singh DK. Molluscicidal activity of Carica papaya and Areca catechu against the freshwater snail Lymnaea acuminata. Vet Parasitol. 2008;152:264-70.

10. Kumar P, Singh DK. Molluscicidal activity of Ferula asafoetida, Syzygium aromaticum and Carum carvi and their active components against the snail Lymnaea acuminata. Chemosphere. 2006;63:1568-74.

11. Kumar P, Singh VK, Singh DK. Combination of molluscicides with attractant carbohydrates and amino acids in bait formulations against the snail Lymnaea acuminata. Eur Rev Med Pharmacol Sci. 2011;15:550-5.

12. Kusumoto IT, Nakabayoshi T, Kida H, Miyashiro H, Hattori M, Namba T, et al. Screening of various plant extracts used in Ayurvedic medicine for inhibitory effect on human immunodeficiency virus type 1 (HIV-1) protease. Phytother Res. 1995;9:180-4.

13. Mali RG, Mahajan SG, Mehta AA. Rakta Kanchan (Bauhinia variegata): chemistry, traditional and medicinal uses. A review. Phog Rev. 2007;1:314-19.

14. Mas-Coma S, Bargues MD, Valero MA. Fascioliasis and other plant-borne trematode zoonoses. Int J Parasitol. 2005;35:1255-78.

15. Mas-Coma S, Valero MA, Bargues MD. Chapter 2 Fasciola, lymnaeids and human fascioliasis with a global overview on disease transmission epidemiology, evolutionary genetics, molecular epidemiology and control. Adv Parasitol. 2009;69:41-146.

16. Mas-Coma S, Valero MA, Bargues MD. Effects of climate change on animal and zoonotic helminthiases. Rev Sci Tech. 2008;27:443-52.

17. Reddy MVB, Reddy MK, Gunasekar D, Caux C, Bodo B. A flavonone and a dihydrobenzoxepin from Bauhinia variegata. Phytochemistry. 2003;64:879-82.

18. Robertson JL, Russell RM, Preisler HK, Savin NE. Bioassay with Arthropods: POLO computer programme for analysis of bioassay data. $2^{\text {nd }}$ ed. Boca Raton: CRC Press; 2007.

19. Sahu NP, Koike K, Jia Z, Nikaido T. Triterpenoid saponins from Mimusops elengi. Phytochemistry. 1997;44:1145-9.

20. San Martin RM, inventor; Dictuc S.A, assignee. US Patent, 20.070196.517. Modified saponin molluscicide, 2007, April 25.

21. Satish S, Raghvendra MP, Mohana DC, Raveesha KA. Antifungal activity of a known medicinal plant Mimusops elengi L. against grain moulds. J Agric Technol. 2008;4:151-65.

22. Shafer TJ, Meyer DA, Crofton KM. Developmental neurotoxicity of pyrethroid insecticides: critical review and future research needs. Environ Health Perspect. 2005; 113:123-36

23. Shah PJ, Gandhi MS, Shah MB, Goswami SS, Santani D. Study of M. elengi bark in experimental gastric ulcers. J. Ethnopharmacol. 2003;89:305-11.

24. Shukla S, Singh VK, Singh DK. The effect of single, binary and tertiary combination of few plant derived molluscicides alone or in combination with synergist on different enzymes in the nervous tissues of the fresh water snail Lymnaea (Radix) acuminata (Lamark). Pesticide Biochem Physiol. 2006;85:167-73.

25. Silva TMS, Batista MM, Camara CA, Agra MF. Molluscicidal activity of some Brazilian Solanum spp (Solanaceae) against Biomphalaria glabrata. Ann Trop Med Parasitol. 2005;99:419-25.

26. Singh A, Singh VK. Molluscicidal activity of Saraca asoca and Thuja orientalis against the fresh water snail Lymnaea acuminata. Vet Parasitol. 2009;164:206-10. 


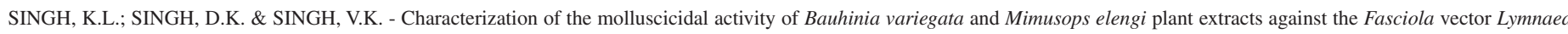
acuminata. Rev. Inst. Med. Trop. Sao Paulo, 54(3): 135-40, 2012.

27. Singh A, Singh, DK, Mishra, TN, Agarwal, RA. Molluscicide of plant origin. Biol Agaric Hortic. 1996;13:205-52.

28. Singh DK, Agarwal RA. Correlation of the anticholinesterase and molluscicidal activity of the latex of Euphorbia royleana Bioss on Lymnaea acuminata. J Nat Prod. 1984;47:702-5.

29. Singh O, Agarwal RA. Toxicity of certain pesticides to two economic species of snails in northern India. J Econ Entomol. 1981;74:568-71.

30. Singh S, Singh VK, Singh DK. Molluscicidal activity of some common spice plants. Biol Agric Hortic. 1997; 14:237-49.

31. Singh VK, Singh DK. Characterization of allicin as a molluscicidal agent in Allium sativum (Garlic). Biol Agric Hortic. 1995;12:119-31.

32. Sokal RR, Rohlf FJ. Introduction to biostatistics. San Francisco: W.H. Freeman; 1996.

33. Sparg SG, Light ME, Staden J. Biological activities and distribution of plant saponins. J Ethopharmacol. 2004;94:219-43.
34. Srivastava P, Kumar P, Singh DK. Control of harmful snails: Tejpat (Cinnamomum tamala). A potential molluscicide. J Appl Biosci. 2005;31:128-32.

35. Upadhyay A, Singh DK. Molluscicidal activity of Sapindus mukorossi and Terminalia chebula against the freshwater snail Lymnaea acuminata. Chemosphere. 2011;83:46874.

36. WHO. Report of the WHO informal meeting on use of Triclabendazole in fascioliasis control. Geneva: WHO Headwaters; 17-18 October, 2006. WHO/CDC/NTD/PCT/ 2007.1.

37. Xu F, Proft J, Gibbs S, Winkfein B, Johnson JN, Syed N, et al. Quercetin targets cysteine string protein (CSP $\alpha$ ) and impairs synaptic transmission. PLoS one. 2010;5:e11045. Doi:10.1371/journal.pone.0011045.

Received: 21 January 2012

Accepted: 7 March 2012 